\title{
A HISTOCHEMICAL AND BIOCHEMICAL STUDY OF THE PAROTID GLAND IN NORMAL AND HYPOPHYSECTOMIZED RATS 1,2
}

\author{
MAYNARD M. DEWEY ${ }^{3}$ \\ Department of Anatomy, University of Michigan Medical School, \\ Ann Arbor
}

TWENTY FIGURES

Baker and Abrams ('55) demonstrated a marked reduction in weight of the parotid gland after hypophysectomy. Concurrently, the acinar cells became smaller, were depleted of zymogenic granules and their amylase content was reduced (Baker et al., '56). These observations suggest that maintenance of the normal structure and function of the parotid gland is dependent on the action of hormones.

Additional interest in the relationship of the parotid gland to the endocrine system is created by the postulation that it is itself an endocrine organ. Ito ('54) and Ito and Okabe ('55) reported the chemical characteristics of a purified protein which they called parotin, that was extracted from the parotid gland of cattle and from human saliva. It was believed to be the salivary gland hormone described previously by Ogata (cited by Ito, '54). The following observations led to the theory that secretion of parotin mediates the action of pituitary growth hormone. The tibial epiphysis failed to respond to pituitary growth hormone in hypophysectomized-sialo-

\footnotetext{
${ }^{1}$ Based on a dissertation submitted in partial fulfilment of the requirements for the Doctor of Philosophy degree in the School of Graduate Studies, University of Michigan.

'Deep appreciation is extended to Dr. Burton L. Baker for his direction of this investigation and to Dr. Robert L. Hunter for his aid in preparing the zymograms.

${ }^{8}$ Public Health Service Research Fellow of the National Institute of Arthritis and Metabolic Diseases.
} 
adenectomized rats (Shibata et al., '54). The acidophils of the anterior hypophysis hypertrophied after sialoadenectomy (Akazaki, eited by Shibata et al., '54), and conversely, hypofunction of the thyroid and reduction in the number of acidophils in the anterior hypophysis occurred after chronic administration of parotin (Tasaka, eited by Shibata et al., '54).

The objectives of this study were (a) to elucidate the histochemical and biochemical characteristics of the parotid gland in nonhypophysectomized and hypophysectomized rats, and (b) to provide basic information for a re-evaluation of the possible endocrine role of the parotid gland.

\section{MATERIALS AND METHODS}

Young, adult male Sprague-Dawley rats were maintained in individual cages and fed a diet consisting of Purina Laboratory Chow. The animals were given water ad libitum but no food 24 hours prior to the termination of an experiment. The parotid glands were excised while the animals were under sodium amytal anesthesia.

Hypophysectomy. Beginning 10 to 15 days after hypophysectomy, a nonhypophysectomized control animal was pair-fed against each operated rat. The completeness of hypophysectomy was ascertained by microscopic examination of serial sections of the pituitary region or by the reduced body weight. Incompletely hypophysectomized rats were discarded.

Forty hypophysectomized and 40 nonhypophysectomized control rats were utilized. The mean body weight of the hypophysectomized animals was $181 \pm$ standard deviation $4.8 \mathrm{gm}$ before the operation and $142 \pm 5.8 \mathrm{gm}$ at the termination of the experiment; for the nonhypophysectomized animals it was $185 \pm 1.2 \mathrm{gm}$ and $184 \pm 4.1 \mathrm{gm}$, respectively. The postoperative period was 40-111 days and did not vary more than 20 days for the animals used for any one procedure. Several technical procedures were carried out on the parotid glands from each animal (table 1).

Histological and histochemical techniques. Small pieces of parotid gland were fixed in Zenker-formol, Regaud's fluid, 

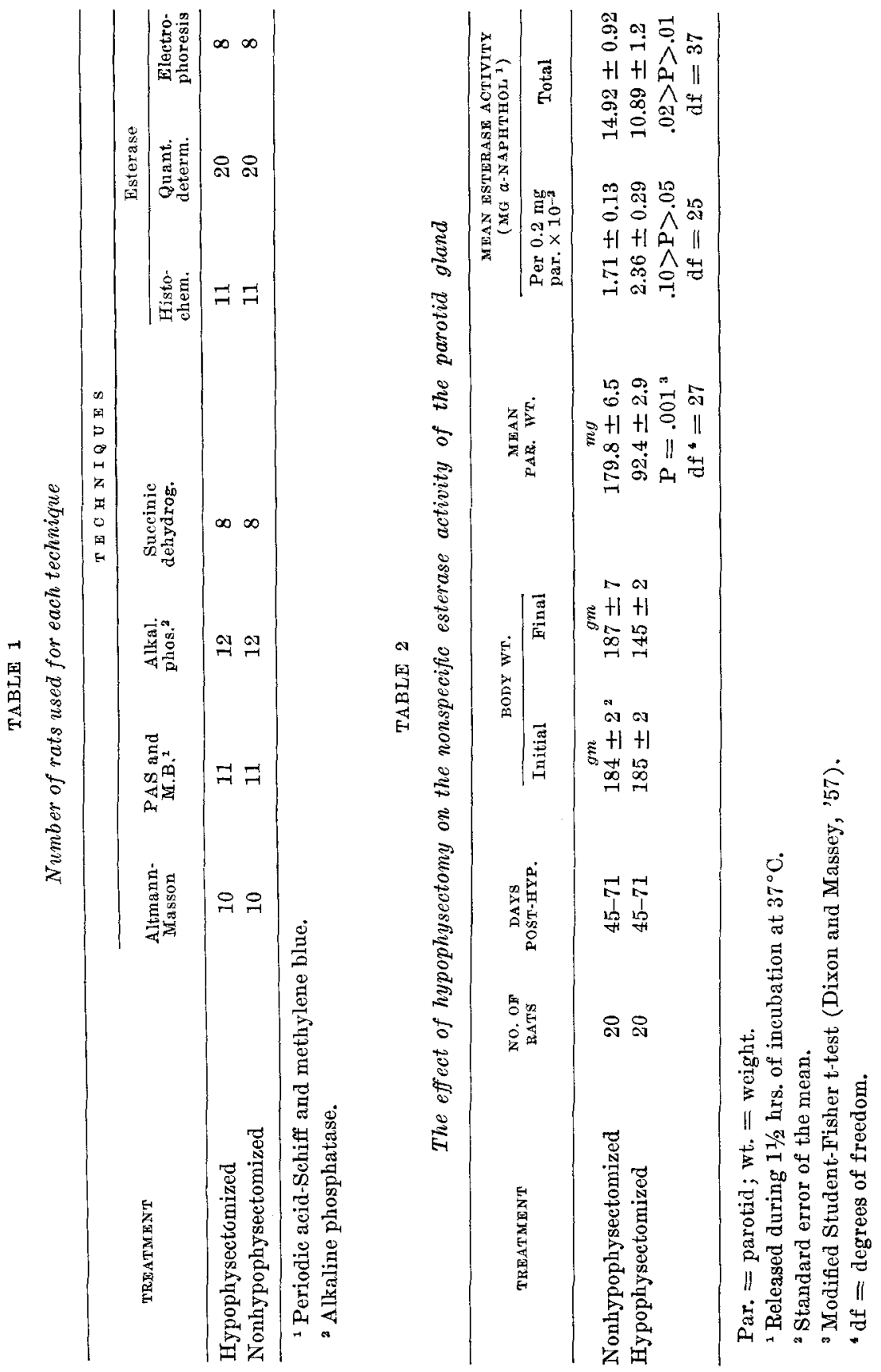
formalin-alcohol-acetic acid (FAA) and $1 \%$ trichloracetic acid in $80 \%$ ethanol. Specimens fixed in Zenker-formol and Regaud's fluid were treated subsequently with $3 \% \mathrm{~K}_{2} \mathrm{Cr}_{2} \mathrm{O}_{7}$ and double-embedded in celloidin and paraffin. Fixation in FAA and subsequent dehydration were carried out at $2{ }^{\circ} \mathrm{C}$. These tissues were embedded in paraffin.

For the demonstration of mitochondria and zymogenic granules, sections of the glands fixed in Zenker-formol or Regaud's fluid were stained with Regaud's hematoxylin and the Altmann-Masson procedure (Severinghaus and Thompson, '39). For glycogen, carbohydrate-containing proteins, and nucleic acids, sections of specimens fixed in FAA were stained with the periodic acid-Schiff (PAS) technique (Hotchkiss, '48) and counterstained with methylene blue ( $\mathrm{pH}$ 5.6). To verify which basophilic substances were composed of ribonucleic acid, sections were digested in a $1 \%$ ribonuclease at $37^{\circ} \mathrm{C}$ before staining; control sections were incubated in distilled water. In order to show which PAS-staining substances were glycogen, some sections were digested in $1 \%$ a-amylase ( $\mathrm{pH}$ 7.0) while other control preparations were incubated in the buffer solution without amylase.

Alkaline phosphatase was demonstrated on FAA-fixed specimens by the Gomori technique ('39), sodium glycerophosphate, fructose-diphosphate, glucose-6-phosphate, yeast nucleic acid and adenylic acid being used as substrates. Control sections were heated in boiling water, prior to incubation. Sulfhydryl and disulfide groups were studied on the trichloracetic acid-fixed glands by the method of Barrnett and Seligman ('52). Succinic dehydrogenase was demonstrated by the technique of Farber and Louviere ('56) in sections of nonfixed glands prepared in a Cryostat. They were incubated anaerobically. Other sections, which were incubated in a medium containing no sodium succinate, served as controls. Gomori's ('52) technique, with $\alpha$-naphthol butyrate as the substrate, was used to localize nonspecific esterase activity in nonfixed preparations which had been sectioned in a Cryostat. Garnet GBC served as the azo dye. The tissue was fixed 
in formol-saline after incubation. Control sections were incubated in a medium which did not contain a-naphthol butyrate.

Biochemical techniques. Nonspecific esterases also were studied by the quantitative procedure of Gomori ('53) and the starch gel electrophoretic method of Hunter and Markert ( 57) for separation of the enzymes. For the quantitative procedure, an aliquot of the homogenized gland was incubated at pH 7.0 in a solution containing a-naphthol butyrate and the azo-dye, diazotized-4-diethylsulfonamide-2-aminoanisole. Activity, as determined with a Klett colorimeter, was expressed by reference to a standard curve worked out with known quantities of $\alpha$-naphthol in the substrate.

For the separation of nonspecific esterases by starch gel electrophoresis, small pieces of filter paper were saturated with the clear supernatant obtained from a centrifuged homogenate of the gland and inserted into starch strips buffered with a $0.03 \mathrm{M}$ borate buffer at $\mathrm{pH} 8.5$. After $4 \frac{1}{2}$ hours, esterases were visualized by incubating the strips at $\mathrm{pH} 7.0$ in substrates containing a-naphthol butyrate or a-naphthol ace. tate and Garnet GBC.

Measurement of ducts and height of their epithelium. Sections stained with PAS and methylene blue were utilized in determining the effect of hypophysectomy on the diameter of the salivary portion of intralobular ducts and the height of their epithelium. The smallest diameter was recorded only for those intralobular ducts which were cut transversely. Measurements were made on 25 ducts in a single section from each animal. The data so obtained were treated statistically by variance analysis (Snedecor, '56; Ostle, '54).

\section{OBSERVATIONS}

The normal parotid gland

Acinar cells. After fixation in Zenker-formol or Regaud's fluid, the abundant zymogenic granules were of uniform size and morphology and stained intensely with aniline blue (fig. 1). 
Following fixation in FAA, fewer granules were preserved, more being present in smaller acini than in the larger ones. The granules stained lightly with the PAS procedure. The cytoplasm of acinar cells stained with methylene blue (fig. 3) due to the presence of ribonucleic acid since this staining capacity was lost after digestion with ribonuclease. No glycogen was observed. Mitochondria, which varied in shape from rods to filaments, were distributed uniformly throughout the cytoplasm. The nucleus usually contained a single prominent nucleolus and was compressed against the basal membrane of the cell by the abundant zymogenic granules.

Two types of cytoplasmic inclusion bodies were observed occasionally in all nonhypophysectomized animals. One type, which appeared to be of cytoplasmic origin, was spherical, internally vacuolated, surrounded by a halo, and stained with PAS and aniline blue (fig. 6). It varied in size, sometimes filling the entire cytoplasmic space. The second type (fig.6) appeared to be of nuclear origin. It was spherical, homogeneous and intensely basophilic. Although variable in size, it often was larger than a typical nucleus. When present, no nucleus was observed, and the smaller ones appeared to have resulted from karyorrhexis.

Sulfhydryl groups were stained in the cytoplasm, chromatin and the nuclear membrane. Incubation in thioglycolic acid, which reduces the disulfide groups to sulyhydryl groups, intensified the color (fig. 5). Since zymogenic granules were not preserved by the fixation, their content of sulfhydryl and disulfide groups could not be determined.

No alkaline phosphatase was observed. The slight darkening of nuclei and cytoplasm was an artifact since it appeared in the control slides. However, alkaline phosphatase was present in the myo-epithelial cells surrounding portions of the acini (fig. 10). These cells were more uniformly active about acini which were located close to intercalated ducts. The periacinar capillaries exhibited a high degree of activity. The acinar cells contained a high concentration of esterase (fig. 15) 
when $\alpha$-naphthol butyrate was used as the substrate; naphthol AS acetate gave negative results.

Succinic dehydrogenase was demonstrated throughout the cytoplasm of acinar cells (fig. 17). This distribution correlated well with that of mitochondria. Within two hours after preparation of these slides, rather large pink droplets appeared within the acinar cells. They were of unknown nature but apparently dissolved the reduced neotetrazolium crystals.

Intercalated ducts. The intercalated ducts were long, branched, and narrow. Their transition into the salivary portion of the intralobular ducts was abrupt. The ductular epithelium was squamous and extended into the acinus. After Zenker-formol fixation, the nucleus of the cell was elongated and contained coarse chromatin granules. The mitochondria were fine granules or short rods and were distributed in all parts of the cell. Basophilic material accumulated near the nucleus and extended more diffusely throughout the eytoplasm. It was not observed after digestion with ribonuclease. The epithelial cells contained granules which stained with aniline blue or PAS (fig. 3). They were most abundant in the portion of the duct nearest the acinus and were resistant to digestion with a-amylase.

With the procedure for sulfhydryl groups alone, and for sulfhydryl and disulfide groups together, intercalated ducts stained more intensely than acinar cells (fig. 5). The intensity of the reaction was correlated with the abundance of cytoplasmic granules. It was inferred that the granules contained a moderate concentration of sulfhydryl and disulfide groups.

The myo-epithelial cells and the basal cytoplasm of the intercalated duct epithelium contained a large concentration of alkaline phosphatase (fig. 10). Little activity was observed in the more apical cytoplasm of the ductular cells except for the luminal border. The endothelium of the capillaries associated with these ducts exhibited a moderate amount of phosphatase.

No difference in localization of alkaline phosphatase was observed with the various substrates utilized for the demon- 
stration of the enzyme. However, variation was noted in the degree of activity and sharpness of localization. Sections incubated with fructose-diphosphate as the substrate showed the greatest blackening of the active areas. Little difference was observed when sodium glycerophosphate and glucose-1phosphate were used. Adenylic acid and yeast nucleic acid gave the least activity and sharpness of localization.

Esterase was present throughout the length of the intercalated ducts (fig. 15). The level of activity was comparable to that observed in acinar cells. The succinic dehydrogenase system was operative in the epithelial cells lining the intercalated duct (fig. 17).

Intralobular, interlobular and excretory ducts. ${ }^{4}$ The PAS procedure stained the cytoplasm, basal striations and luminal border of the epithelium (figs. 7, 9). Sparsely distributed granules were observed in the perinuclear and apical portions of the cell (fig. 9); they stained weakly with PAS and were amylase-resistant. Glycogen was observed rarely.

Basophilic material was present in the apical portion of the epithelial cytoplasm and less often in the middle and basal parts of the cell. It varied in form from a diffuse reticulum to clumps. This basophilia was ascribed to the presence of ribonucleic acid since it was not observed after digestion with ribonuclease. The cytoplasm of epithelium in the intralobular and interlobular ducts was a deep rose color after application of the procedure for sulfhydryl groups and prior reduction with thioglycolic acid intensified this reaction (fig. 5). Basal striations were delineated clearly.

No alkaline phosphatase was observed (fig. 10). The capillaries and arterioles associated with the salivary ducts usually exhibited less activity than those surrounding the acini. Those adjacent to the interlobular and excretory ducts were always blackened intensely.

\footnotetext{
"The term "excretory duct" encompasses the larger branches of the duct system, which were isolated by the presence of extensive connective tissue and possessed no intimate positional relationship to the parenchymal lobules.
} 
The greatest esterase activity of the parotid gland was localized in the intralobular, interlobular, and excretory ducts. However, this varied in degree between ducts and between cells within a single duct (fig. 13). Esterase was most active in the basal portion of the epithelium. Little or none could be demonstrated with naphthol AS acetate as the substrate.

Succinic dehydrogenase was highly active in the epithelium of the intralobular, interlobular and excretory ducts (figs. 17, 18), the distribution of the reduced neotetrazolium corresponding with that of mitochondria. This relationship was quite obvious in the excretory ducts (fig. 19) where the cells were taller and had, proportionately, more apical cytoplasm containing no mitochondria. As compared with the ducts, the lesser deposition of neotetrazolium salt in the acinar cells was proportional to the smaller concentration of mitochondria found in them.

Separation of esterases by electrophoresis. Zymogram B (fig. 20) shows the two distinct esterase-reactive bands which were present in all cases. No difference was observed when either $a$-naphthol butyrate or a-naphthol acetate was employed as the substrate. Neither band was demonstrated after incubation with naphthol AS acetate. Zymogram $\mathrm{C}$ reveals the esterase-reactive bands from a liver homogenate. This illustrates the constant relationship of migration of the reactive proteins of the parotid gland to those of the liver.

\section{The parotid gland after hypophysectomy}

Acinar cells. A marked atrophy of the acinus occurred after hypophysectomy with reduction in the number and size of the intracellular zymogenic granules (fig. 2). After Zenkerformol fixation, most cells contained no zymogenic granules at all or only a few small ones in their most apical portion. A few cells, however, were filled with small zymogenic granules. These granules were usually brown and rarely stained as intensely with aniline blue as did those of the nonhypophysectomized animals. After fixation with Regaud's fluid, small zymogenic granules were preserved in all acinar cells. With 
the PAS procedure, the few granules present also stained less intensely than in nonhypophysectomized rats (fig. 4).

The cytoplasm was as strongly basophilic as in nonhypophysectomized controls. In the basal portion of the cell, large intensely basophilic clumps appeared which were either homogeneous or lamellar (fig. 4). The incidence of the two types of peculiar cytoplasmic inclusions was increased by hypophysectomy with probable involvement of more cells within an acinus. No change was observed after hypophysectomy in the cytoplasmic reaction for sulfhydryl groups alone or for sulfhydryl and disulfide groups together.

Alkaline phosphatase was reduced markedly in the myoepithelial cells associated with the acini (figs. 11, 12), none being observed except on rare occasions. The activity of the peri-acinar capillaries was reduced but less uniformly. No alteration appeared in succinic dehydrogenase (fig. 18) while the basal concentration of esterase was increased (fig. 16).

Little change was observed in the morphology of either the nucleus or mitochondria. In those acini containing little granulation or vacuolation, the nucleus was more spherical and occupied a more central position than in nonhypophysectomized rats. Mitochondria were decreased in number commensurate with the decrease in cell size and restricted to the perinuclear and basal positions of the cell.

Intercalated ducts. After hypophysectomy, the intercalated ducts appeared somewhat wider, shorter and with a slightly thicker epithelium (fig. 4). The cytoplasmic granules were fewer in number but remained of the same size and morphology as those seen in the glands from nonhypophysectomized animals. Their depletion was seen most clearly in those cells nearest the salivary ducts. Basophilia of the epithelium was not altered. The concentration of sulfhydryl and disulfide groups was reduced commensurate with the reduction in cytoplasmic granules. Phosphatase (fig. 11), esterase (fig. 16) and succinic dehydrogenase (fig. 18) were not changed in distribution or degree of activity. 
Intralobular, interlobular and excretory ducts. Little change occurred in the cytology of the cells lining the intralobular, interlobular and excretory ducts after hypophysectomy. These cells appeared somewhat narrower and the mitochondria more dense (fig. 2).

The mean diameter of the intralobular ducts in nonhypophysectomized animals was $20.9 \pm$ standard deviation $0.17 \mu$ and in hypophysectomized animals, $21.1 \pm 0.15 \mu$. The height of the epithelium was $8.1 \pm 0.08 \mu$ for the control glands and $8.3 \pm 0.06 \mu$ after hypophysectomy. These differences were not significant. Variance analysis showed highly significant differences between animals in both groups. These differences were not due to variation in body weight or duration of the postoperative period.

After hypophysectomy, the cytoplasm of epithelial cells lining the interlobular, intralobular and excretory ducts stained less intensely with PAS than in nonhypophysectomized animals. The basal striations, luminal border, and basement membrane reacted similarly. The most prominent alteration was an irregular increase in the amount of glycogen (fig. 8 ) in the epithelium of interlobular and excretory ducts. It occurred chiefly in the apical cytoplasm. The interlobular ducts rarely showed such large accumulations. Occasionally glycogen occurred basally between the vertical striations. In all three portions of the duct system, great variation was observed in the amount of glycogen within different cells of one duct and between different ducts. Cytoplasmic basophilic material was reduced slightly by hypophysectomy. No change was observed in either the distribution or intensity of staining for sulfhydryl groups alone or sulfhydryl and disulfide groups together.

As in the controls, no alkaline phosphatase was observed in either the intralobular (fig. 12), interlobular or excretory ducts after hypophysectomy nor did a reduction occur in the vessels associated with interlobular and excretory ducts. $\mathrm{Hy}$ pophysectomy had no effect on the succinic dehydrogenase system (fig. 18). Of the 11 glands studied from hypophysec- 
tomized animals, 9 exhibited a marked fall in the esterase activity of the intralobular and interlobular duct cells (fig. 14) but this did not occur in the main excretory ducts (fig. 14).

Biochemical determination of esterase. A tendency toward an increase in the concentration of esterase occurred after hypophysectomy. The difference between a mean of $23.6 \pm$ standard error $2.9 \mu \mathrm{g}$ of $\alpha$-naphthol $/ 0.2 \mathrm{mg}$ of tissue for hypophysectomized animals and $17.1 \pm 1.3 \mu \mathrm{g}$ for the nonhypophysectomized animals was not significant (table $2, .10>\mathrm{P}>$ $.05)$. However, when expressed in terms of total concentration, a reduction from $14.92 \pm 0.92 \mathrm{mg}$ of a-naphthol for the nonhypophysectomized animals to $10.89 \pm 1.2 \mathrm{mg}$ for the hypophysectomized rats was observed. This difference was significant at the one to two per cent level. A test of variance homogeneity in the various groups showed a significant lack of homogeneity. Since the Fisher t-test assumes variance homogeneity, a modified form of the test was used here. The length of the postoperative period had no linear effect upon the results.

Separation of esterases by electrophoresis. Hypophysectomy had no effect on the esterase-active bands which were obtained with starch gel electrophoresis (fig. 20, zymogram A). This applies to the intensity with which the bands stained and the distance which they migrated. Although the starch column was often digested at one end by the amylolytic activity of glands from nonhypophysectomized rats, this was not observed in the preparation of zymograms from hypophysectomized animals. A marked reduction in amylase content of the gland was observed after pituitary ablation (Baker et al., '56).

\section{DISCUSSION}

\section{The normal gland}

Acinar cells. In contrast to the findings of Noback and Montagna ('47), who observed only a faint apical basophilia in acinar cells, this study revealed a significant affinity of the entire cytoplasm for methylene blue. Since the zymogenic 
granules stained lightly with PAS, it may be inferred that they contain carbohydrate. Similar results were obtained by Lillie ('51) in man and some rodents. Duff and Corbett ('45) also found cytoplasmic inclusions in the pancreas of mice, rats, and rabbits and in the salivary glands of the rat. They suggested a viral etiology for them.

Although Deane ('47) described the presence of alkaline phosphatase in acinar cells, and Noback and Montagna ('47) reported activity in the basal portions of the cell with only a faint apical reaction, no alkaline phosphatase was observed in the acinar cells in this material. The myo-epithelial or basket cells associated with the acini were intensely reactive, in agreement with the findings of Silver ('54) in sheep. Similarly, the myo-epithelial cells of the rat, guinea pig and human mammary gland (Dempsey, Bunting and Wislocki, '47) and of the eccrine and apocrine sweat glands of man (Kopf, '57) are exceedingly active. The function of this cell type in the parotid gland and the significance of its high concentration of alkaline phosphatase remain obscure. The intense alkaline phosphatase activity found in capillaries, arterioles and venules associated with the acini, agrees with the observations of Deane ('47) and Hill and Bourne ('54).

There is disagreement concerning the presence of nonspecific esterase in acinar cells. Chessick ('53) found no activity; Hill and Bourne ('54) observed slight activity throughout the cytoplasm and near the Golgi area ; and Burstone ('56) found a "slight overall background reaction." The pronounced activity observed in the acini in the present investigation is undoubtedly due to better preservation of the enzyme by avoidance of fixation. The significant concentration of esterase within acinar cells indicates that it has an important metabolic role.

The distribution of succinic dehydrogenase reported here agrees with that described by Padykula ('52) even though the improved method of Farber and Louviere ('56) was employed. It is believed that this technique "actually localizes a carrier which reacts with succinic dehydrogenase" rather 
than with the enzyme itself (Farber, Sternberg and Dunlap, $56)$.

Intercalated ducts. The cytological and histochemical characteristics of the epithelium lining intercalated ducts strongly suggest that they perform a secretory function. The presence of cytoplasmic granules and the postulation that they represent the stored secretion of these cells were reported by Ito and Narita (cited by Yoshimura, '56). Hill and Bourne ('54) described their marked affinity for leucofuchsin subsequent to oxidation with periodic acid. The present work is in agreement with these findings. The granules probably contain a mucoprotein since they are resistant to digestion with saliva (Hill and Bourne, '54).

Also suggestive of a secretory function was the high activity of alkaline phosphatase, esterase and succinic dehydrogenase in the epithelium. With respect to alkaline phosphatase, this was in sharp contrast to the remaining portions of the duct system. The intense activity of the underlying myo-epithelial cells raises the possibility that the blackening of intercalated ducts may have been an artifact due to diffusion of the reaction products or the enzyme itself (Gomori, '52). The intensity and consistency of the reaction make this seem improbable. Finally, the granules are depleted and cytoplasmic ribonucleic acid increased following stimulation with pilocarpine (Dewey, unpublished).

Intralobular, interlobular and excretory ducts. The intralobular, interlobular and excretory ducts of the rat parotid gland were similar cytologically, except that the epithelium became taller and the basal striations higher and more prominent in progression towards the excretory duct. In the region of transition from intralobular to intercalated duct, few basal striations were present.

Much effort has been expended in attempts to demonstrate a secretory function by these ducts (Babkin, '50; Hill and Bourne, '54). As yet one can only point to the occurrence of various enzymes as being indicative of a high rate of metabolic activity, i.e., nonspecific esterase (Chessick, '53; Hill and 
Bourne, '54; Burstone, '56), succinic dehydrogenase (Padykula, '52) and alkaline phosphatase (Deane, '47; Noback and Montagna, '47; Hill and Bourne, '54). With a few exceptions, this investigation agrees with these findings. In contrast to Deane ('47) and Noback and Montagna ('47), who described alkaline phosphatase in the epithelium of the salivary duct, and Hill and Bourne ('54), who reported it to be present in the distal edges of some cells lining the larger intralobular and interlobular ducts, no activity was observed in either type of duct. Deane's photomicrographs suggest that she was dealing with intercalated ducts rather than salivary ducts. That these cells have an important function is suggested also by the presence of a large number of mitochondria, cytoplasmic PAS-stained granules (Hill and Bourne, '54) and ribonucleic acid. Bixler, Muhler, Webster and Shafer ('57) reported the absence of stainable ribonucleic acid in these cells; the observations of Noback and Montagna ('47) and this investigation disagree with their conclusion.

\section{The effects of hypophysectomy}

In addition to the partial atrophy and degranulation of acinar cells after hypophysectomy (Baker and Abrams, '55; Yoshimura, '56), the granules were also smaller and stained less intensely with aniline blue and PAS. The latter observation indicates that the granules were altered qualitatively as well as quantitatively. In contradiction to Bixler, Muhler, Webster and Shafer ('57), no decrease in the content of ribonucleic acid in acinar cells was observed. This is of particular interest in view of the important role played by ribonucleic acid in protein synthesis (Brachet, '55). The reduced capacity of the acinar cells to synthesize protein as evidenced by the reduced content of zymogenic granules and amylase cannot be ascribed to a reduced ribonucleic acid concentration. It is possible, however, that hypophysectomy induces a chemical change in this component.

Study of various enzymes in the acinar cell did not reveal a fundamental defect. The lack of change in the succinic de- 
hydrogenase, which is concentrated in mitochondria, indicates that at least with respect to this enzyme, the mitochondria are probably unaffected by hypophysectomy. However, alkaline phosphatase was clearly reduced in the peri-acinar capillaries. If this enzyme plays a role in transport of metabolites as postulated for the renal tubular epithelium and the absorptive epithelium of the small intestine (Knox, Auerbach and Lin, '56), a reduction in phosphatase in the parotid gland might lead to impaired transport of similar substances. This condition could be involved in the atrophy of acinar cells after hypophysectomy. Similar reductions in the concentration of alkaline phosphatase in capillaries of the thyroid, testis, and skeletal muscle after hypophysectomy and in the seminal vesicle and uterus after gonadectomy, were described by Dempsey, Greep and Deane ('49).

In contrast to the observations of Yoshimura ('56), hypophysectomy caused a reduction in the number of cytoplasmic granules in the epithelium of interealated ducts. Also in disagreement with Yoshimura ('56), no atrophy was observed in the epithelium of salivary ducts. This was evident not only in the lack of significant change in the cytology or sulfhydryl and disulfide content but also in the lack of significant alteration in either cellular height or diameter of the duct. In these respects, the interlobular and excretory ducts also appeared unchanged. It is certain, however, that some alteration of the physiology of these cells occurred. The accumulation of glycogen, as described by Yoshimura ('56) and confirmed here, slight reduction in PAS-staining, somewhat diminished basophilia and the marked drop in nonspecific esterase activity of the salivary and interlobular ducts were probably indicative of depressed metabolism. The absence of change in the activity of the succinic dehydrogenase system correlated well with the lack of modification in mitochondria. Although starch gel electrophoresis did not reveal a change in esterases after hypophysectomy when sections were examined histochemically, significant alteration in their localization was observed. The marked reduction in esterase activity in the salivary and in- 
terlobular ducts was partially offset by the increased concentration which occurred in the basal portion of the acinar cells. Nevertheless, correlated with the partial atrophy of the gland, the total esterase content was reduced significantly.

The cytology of the acinar cells in the parotid gland seemed to be affected less by hypophysectomy than was that of the gastric chief cells (Baker and Abrams, '54, '55; Baker, '57), pancreatic acini (Baker and Pliske, '57), or the epithelium of the serous tubules in the submandibular gland (Lacassagne and Chamorro, '40; Gabe, '50). The severe reduction observed in the ribonucleic acid content of the gastric chief cell and pancreatic acini and the reduction in number and size of the mitochondria in the pancreatic acinar cell found no counterpart in the parotid gland. In fact, the acinar cell of the parotid gland after hypophysectomy presented little evidence of impaired secretory function except for the reduction in zymogenic granules. The same was true for the duct system. It appears that the degree of control exercised by the pituitary hormone(s), directly or indirectly through some target organ or other metabolic process, is different for the parotid gland than for the other enzyme-secreting cells. Clarification of the mode of pituitary control over the parotid gland must await additional studies involving ablation of other endocrine glands and replacement therapy with their hormones.

While no definitive conclusions may be reached concerning the postulated endocrine role of the parotid gland, one pertinent inference may be drawn. First, if the salivary ducts are the source of the salivary gland hormone (parotin) (Ogata, cited by Yoshimura, '56), and if its secretion is regulated by somatotropin (Shibata et al., '54), a marked atrophy of the cells lining these ducts would be expected after hypophysectomy. This is not the case.

\section{SUMMARY}

Following hypophysectomy, acinar cells of the parotid gland were smaller and their zymogenic granules were reduced in size, number and staining affinity for aniline blue and the PAS 
procedure. There was no alteration in the activity of the succinic dehydrogenase system, morphology of mitochondria, content of ribonucleic acid or of sulfhydryl and disulfide groups in the acini. Alkaline phosphatase was reduced in the myoepithelial cells and capillaries associated with the acinar cells.

Cytoplasmic granules in the lining cells of intercalated ducts were partially depleted by hypophysectomy. Ribonucleic acid, alkaline phosphatase, succinic dehydrogenase and nonspecific esterase were unchanged in these cells. The height of the epithelium and the width of salivary ducts were not changed. However, ribonucleic acid content, PAS staining and esterase activity were decreased and glycogen was increased in the epithelium of salivary and interlobular ducts. Similar changes were observed in the excretory ducts with the exception of a reduction in esterase activity.

Two esterase-active proteins were demonstrated in homogenates of the gland by starch gel electrophoresis but these were not altered by hypophysectomy. Although the localization of esterase, as determined histochemically, was changed by pituitary ablation, biochemical analysis revealed no alteration in concentration of the enzymes.

It was concluded that the magnitude of hormonal control exerted by the hypophysis over the parotid gland is less than that directed toward gastric chief cells, pancreatic acini, or serous tubules of the submandibular gland. The weight of the evidence obtained is against the concept that the salivary ducts are regulated by pituitary growth hormone.

\section{LITERATURE CITED}

Babkin, B. P. 1950 Secretory Mechanisms of the Digestive Glands. P. B. Hoeber, New York.

BAKER, B. L. 1957 The influence of the hypophysis and adrenals on digestive function. Am. J. Clin. Nutr., 5: 445-452.

BATER, B. L., AND G. D. ABRAMS 1954 Effect of hypophysectomy on the eytology of the fundic glands of the stomach and on the secretion of pepsin. Am. J. Physiol., 177 : 409-412.

1955 Growth hormone (somatotropin) and the glands of the digestive system. In: The Hypophyseal Growth Hormone, Nature and Actions, Smith, R. W., Jr., O. H. Gaebler and C. N. H. Long, ed. McGraw-Hill Book Co. Ine., New York, pp. 107-122. 
BAKER, B. I., J. H. KlegmaN, R. G. LogaN AND R. L. GARNER 1956 Reduction in parotid amylase after hypophysectomy. Endocrinology, 59: 254-255.

BAKer, B. L., AND E. C. PLISKe 1957 Endocrine regulation of zymogenic cells. Symp. Soc. Exp. Biol. XI. The Biological Action of Growth Substances. Ed. by H. K. Porter. Cambridge University Press, Cambridge.

Barrnett, R. J., AND A. M. Seligman 1952 Demonstration of protein bound sulfhydryl and disulfide groups by two new histochemical methods. J. Nat. Cancer Inst., 13: 215-216.

Bixler, D., J. C. Muhler, R. C. Webster ANd W. G. Shafer 1957 Changes in submaxillary gland ribonueleic acid following hypophysectomy, thyroidectomy and various hormone treatments. Proc. Soc. Exp. Biol. Med., 94: $521-524$.

BracherT, J. 1955 Nucleic Acids. II. Ed. by E. Chargaff and J. N. Davidson. Academic Press Inc., New York. Chap. 28, pp. 475-519.

Burstone, M. S. 1956 Esterase of the salivary glands. J. Histochem. Cytochem., 4: $130-139$.

Chessick, R. D. 1953 Histochemical study of the distribution of esterases. Ibid., 1 : $471-485$.

DeAne, H. W. 1947 A cytochemical survey of phosphatase in mammalian liver, pancreas, and salivary glands, Am. J. Anat., 80: 321-359.

Dempsey, E. W., H. Bunting and G. B. Wislock 1947 Observations on the chemical cytology of the mammary gland. Ibid., 81: 309-341.

Dempsey, E. W., R. O. Greep and H. W. DEANE 1949 Changes in the distribution and concentration of alkaline phosphatase in tissues of the rat after hypophysectomy or gonadectomy, and after replacement therapy. Endocrinology, 44: 88-103.

Dixon, W. J., AND F. J. MAssey, JR. 1957 Introduction to Statistical Analysis. 2nd. ed. MeGraw-Hill Book Co., Ine., New York.

DuFF, G. L., AND E. CORBETT 1945 Cytoplasmic inclusion bodies in the pancreas and salivary glands of small laboratory animals. Proc. Soc. Exp. Biol. Med., 59: 99-103.

FARBER, E., AND O. D. Louviere 1956 Histochemical localization of specific oxidative enzymes. IV. Soluble oxidation-reduction dyes as aids in the histochemical localization of oxidative enzymes with tetrazolium salts. J. Histochem. Cytochem., 4: 346-356.

Farber, E., W. H. Sternbera and C. E. Dunlap 1956 Histochemical localization of specific oxidative enzymes. I. Tetrazolium stains for diphosphopy. ridine nucleotide diaphorase and triphosphopyridine nucleotide diaphorase. J. Histochem. Cytochem., 4: 254-265.

GABE, M. 1950 Action de 1'hypophysectomie et des injections d'extraits hypophysaires sur la glande sous-maxillaire du rat albinos. Arch. d'Anat. micro. et Morph. exp., $89: 15-34$.

GoMorI, G. 1939 Mierotechnical demonstration of phosphatase in tissue sections. Proc. Soc. Exp. Biol. Med., 42: 23-26.

1952 Mieroscopic Histochemistry. University of Chicago Press, Chicago.

1953 Human esterases. J. Lab. Clin. Med., 42: 445-453.

HILL, C. R., AND G. H. BouRne 1954 The histochemistry and cytology of the salivary gland duct cells, Acta Anat., 20: 116-128. 
Hotchkiss, R. D. 1948 A microchemical reaction resulting in the staining of polysaceharide structures in fixed tissue preparations. Arch. Biochem., 16 : 131-141.

Hunter, R. I., AND C. L. MARKerT 1957 Histochemical demonstration of enzymes separated by zone electrophoresis in starch gels. Science, 125: 1294-1295.

ITo, Y. 1954 Biochemical studies on salivary gland hormone. Endocr. jap., 1: $1-50$.

ITO, Y., AND S. OKABE 1955 On the occurrence of a parotin-like substance (saliva-parotin) in the human saliva. Studies on the salivary gland hormones. XXVII. Endoer. jap., 2: 195-204.

Knox, W. E., V. H. Auerbach ANd E. C. C. LiN 1956 Enzymatic and metabolic adaptations in animals. Physiol. Rev., $36:$ 164-254.

KoPf, A. W. 1957 The distribution of alkaline phosphatase in normal and pathologic human skin. Am. Med. Assoc. Arch. Derm., 75: 1-37.

Lacassagne, A., and A. Chamorro 1940 Réaction a la testostérone de la glande sous-maxillaire, atrophiée consécutivement à l'hypophysectomie chez la souris. C. R. Soc. Biol., 134: 223-224.

LILLIE, R. D. 1951 Histochemical comparison of the Casella, Bauer, and periodic acid oxidation-Schiff leucofuchsin techniques. Stain Tech., 26: 123-136.

Noback, C. R., AND W. MONTAgna 1947 Histochemical studies of the basophilia, lipase and phosphatases in the mammalian pancreas and salivary glands. Am. J. Anat., 81: 343-367.

Ostre, B. 1954 Statistics in Research. Iowa State College Press, Ames. Pp. 254-257.

PAdrkula, H. A. 1952 The localization of succinic dehydrogenase in tissue sections of the rat. Am. J. Anat., 91: 107-146.

Severinghaus, A. E., AND K. W. Thompson 1939 Cytological ehanges induced in the hypophysis by prolonged administration of pituitary extract. Am. J. Path., 15: 391-412.

Shibata, K., A. Negishi, K. SAIto AND S. Todokoro 1954 Effect of salivary gland-ectomy on the response of the tibial epiphysis to growth hormone. Endocr. jap., 1: 203-208.

SILVer, I. A. 1954 Myoepithelial cells in the mammary and parotid glands. J. Physiol., 125: 8P-9P.

SNEDEcor, G. W. 1956 Statistical Methods. Iowa State College Press, Ames. Pp. 264-268.

YoshimurA, F, 1956 Cytological changes in rat salivary glands following hypophysectomy and somatrophic hormone administration. Okajimos fol. anat. jap., 28: 195-206. 


\section{PLATES}




\section{PLATE 1}

EXPLANATION OF FIGURES

Figs. 1 and 2 Fixation in Zenker-formol, stained with Altmann-Masson, $4 \mu$. $\times 1325$. Figures 3,4 and 6 : fixation in FAA, stained with PAS and methylene blue, $4 \mu . \times 600$. Figure 5 : fixation in trichloracetic acid, stained with sulfhydryl and disulfide procedure: $\times 450$.

1 Nonhypophysectomized control. Acinar eells (above) are engorged with large zymogenie granules. Nuclei are hyperehromatic. In the epithelium of the intralobular or salivary duct (bottom) mitochondria are most concentrated basally.

2 Hypophysectomized 57 days previously. Acinar cells are reduced in size and contain fewer zymogenie granules which are less cyanophilic. Nuclei are less compressed. The intralobular duct epithelium (bottom) is not atrophic but the cells are narrower. Mitochondria are stained more intensely.

3 Nonhypophysectomized control. Acinar cells are vacuolated; the cytoplasm throughout the cell is intensely stained with methylene blue. Epithelial cells lining the intercalated duct are engorged with PAS-positive granules.

4 Hypophysectomized 111 days previously. Cytoplasm of the acinar cell is vacuolated. No loss in intensity of eytoplasmic basophilia is apparent; basal masses of basophilic material are present (arrow). The PAS-positive granules of the interealated duct are reduced in number but not in size.

5 Nonhypophysectomized control. Acinar cytoplasm is lightly stained. No zymogenic granules are seen. Intercalated ducts (I) are more intensely stained than acini. The cytoplasm of the cells in the salivary portion of an intralobular duet (S) is stained intensely.

6 Hypophysectomized 60 days previously. A large homogeneous basophilic (B) and a PAS-positive inclusion (arrow) are seen. 

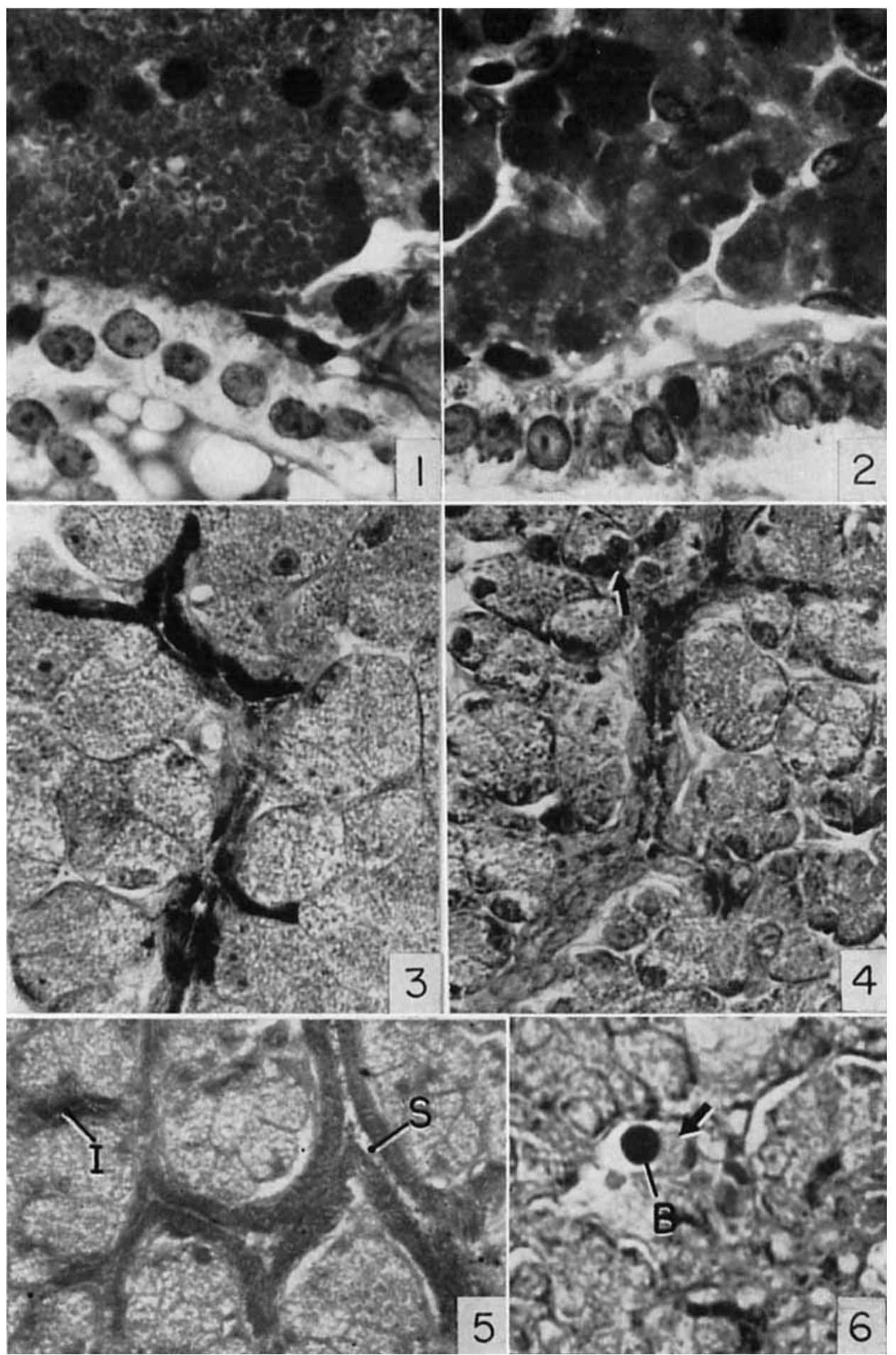


\section{PLATE 2}

\section{EXPI $A N A T I O N$ OF FIGURES}

Figs. 7 and 8 Fixation in FAA, stained with PAS and methylene blue, $4 \mu$. $\times 600$. Figure 9: fixation in FAA, a-amylase digested, stained with PAS and methylene blue. $\times 638$. Figures 10,11 and 12 : fixation in cold FAA, alkaline ghosphatase with sodium glycerophosplate as substrate, $4 \mu . \times 338$.

7 Nonhypophysectomized control. The eytoplasm of the epithelium of the interlobular ducts is stained lightly by PAS. A fine, sparse granulation is seen throughout the eytoplasm. The basal striations (arrow) and the basement membrane are stained with PAS.

8 Hypophysectomized 110 days previously. Large accumulations of glyeogen are present in the cells lining the salivary (S) and interlobular ducts (R).

9 Hypophysectomized 46 days previously. Amylase digestion removed all of the intensely PAS-staining material from the ducts (compare with fig. 8). The staining of basal striations and fine cytoplasmic granulation is unchanged.

10 Nonhypophysectomized control. Alkaline phosphatase is possibly present in the intercalated ducts (I) and definitely present in the myo-epithelial cells associated with the acini (arrow). Arterioles (A) and peri-acinar capillaries (C) show marked activity while the venules (V) are less active. The salivary portion of the intralobular duet (\$) is negative.

11 Hypophysectomized 40 days previously. Phosphatase activity is unchanged in the intercalated duet (I) but reduced in peri-acinar capillaries (arrow).

12 Hypophysectomized 40 days previously. No alkaline phosphatase is observed in the salivary duct (S). The aetivity of myo-epithelial cells is reduced. 


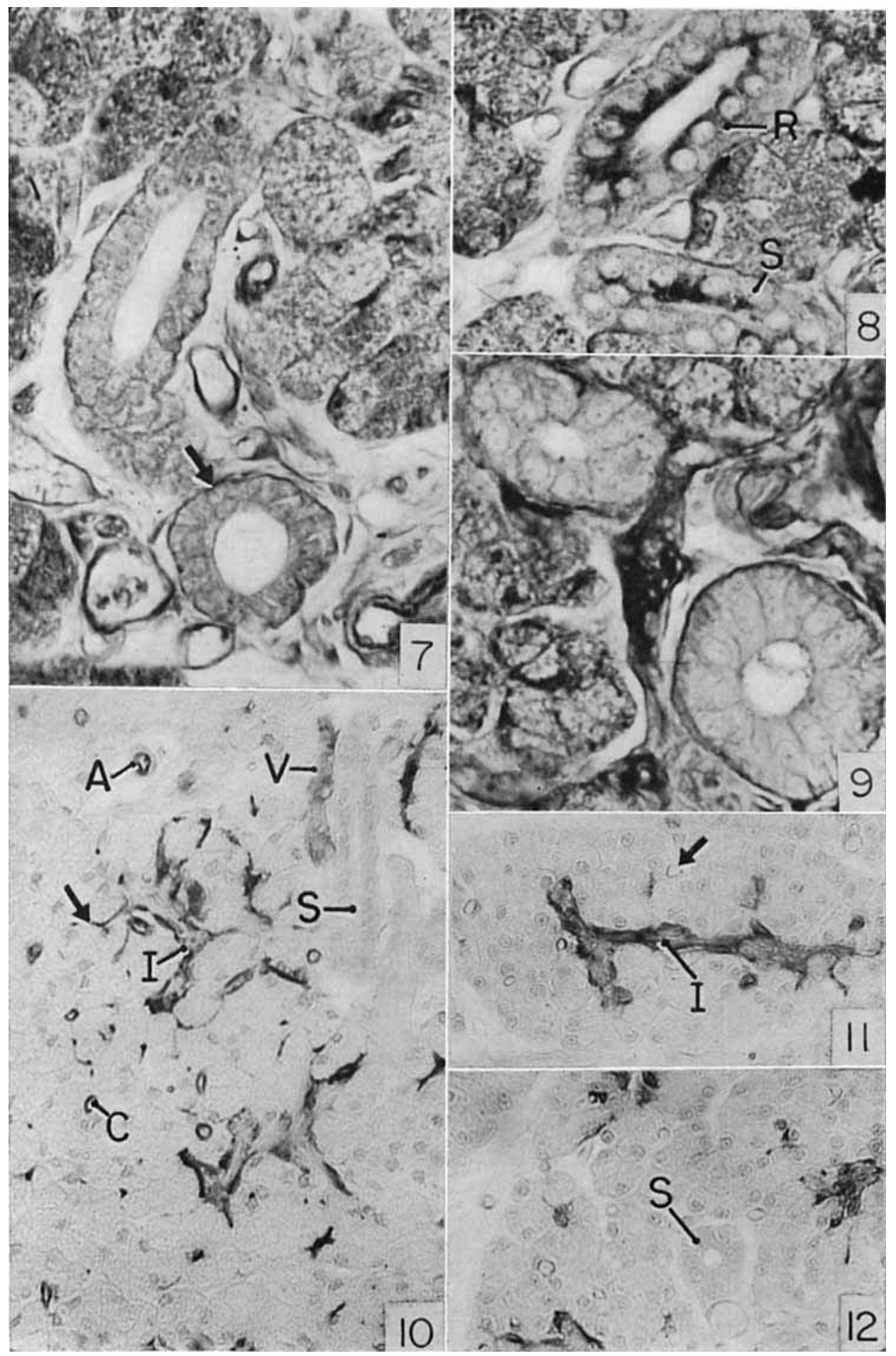


PLATE 3

EXPLANATION OF FIGURES

The parotid glands for figures 13 through 16 were scetioned in a Cryostat at $10 \mu$. Incubated with $a$-naphthol butyrate and Garnet GBC for esterase. Figures 13 and $14: \times 64$. Figures 15 and $16: \times 338$.

13 Nonhypophysectomized control. The majority of the salivary (S) and interlobular ( $R$ ) ducts and the large exeretory duct (bottom) show intense esterase activity. Variation in activity among cells within all ducts is apparent.

14 Hypophysectomized 46 days previously. Esterase in acini and the large excretory duct is unchanged. The activity in salivary (S) (intralobular) and interlobular ducts $(R)$ is reduced.

15 Nonhypophysectomized control. The apparent reduction in acinar size is an artifact. Considerable esterase is distributed uniformly throughout the cytoplasm of the acinar cells. $\Lambda$ comparable degree of activity is seen in the interealated duct (I), while the abrupt transition of this duct into the salivary duct is clearly marked by the greater activity of the latter (S).

16 Hypophyscetomized 44 days previously. Esterase is not reduced in the acini or intercalated duct (I). Comparison with figure 15 reveals a basal concentration (arrow) of activity in the acinar cells. The activity of the salivary (intralobular) duct (S) is reduced. 


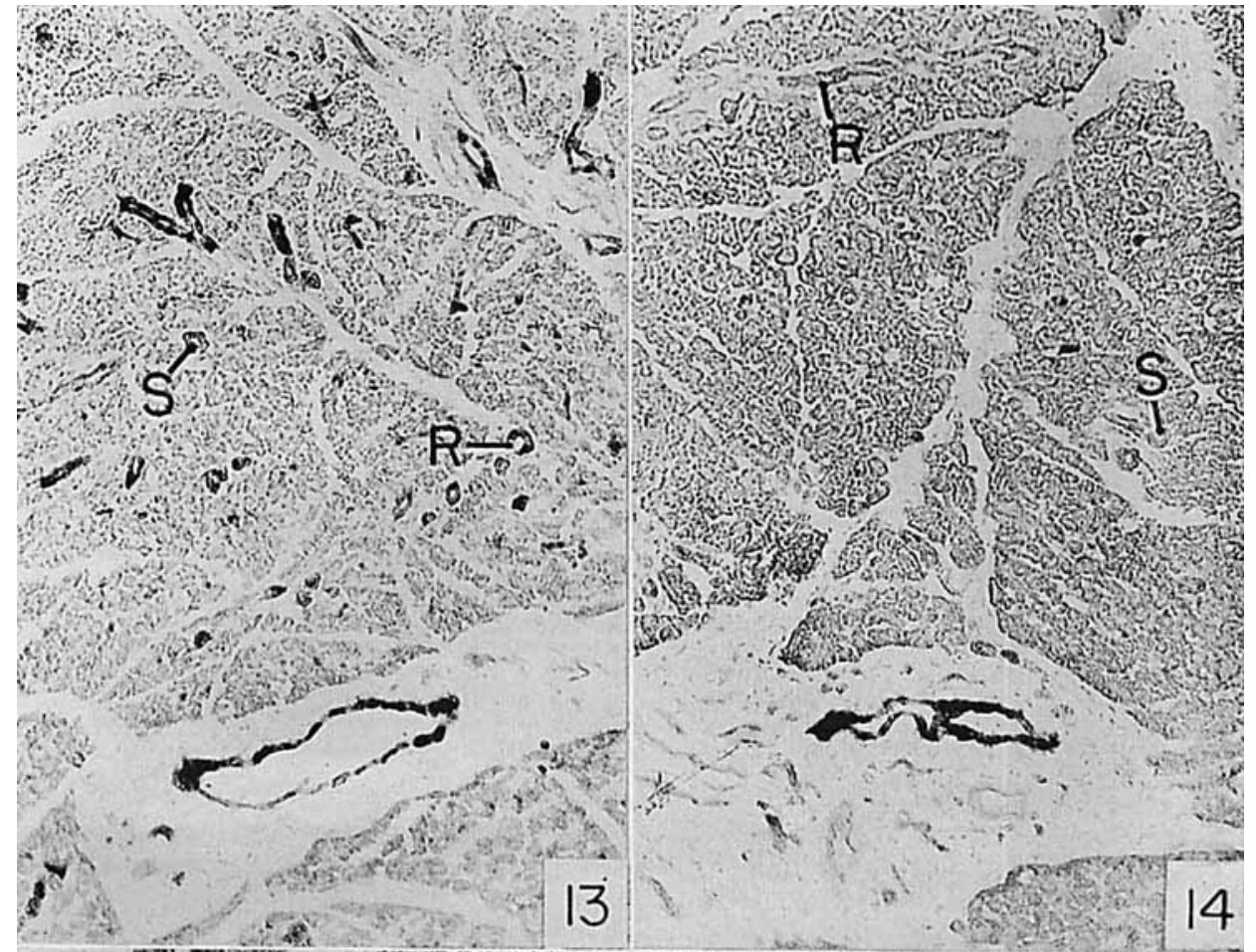

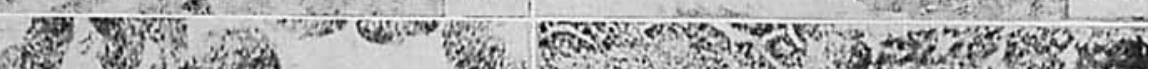

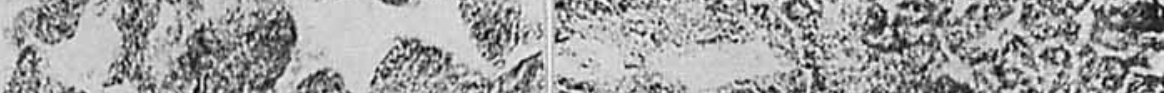

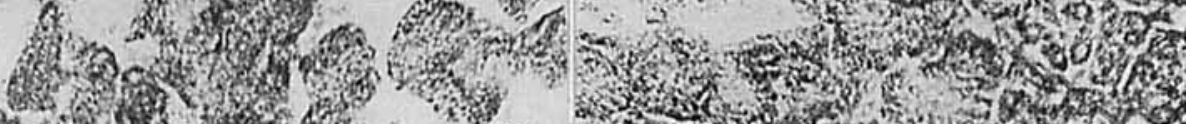

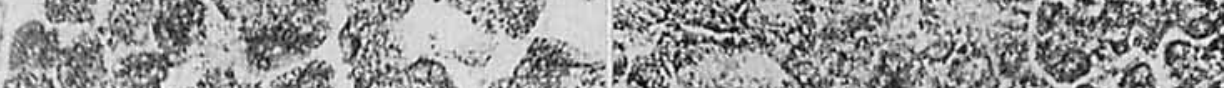

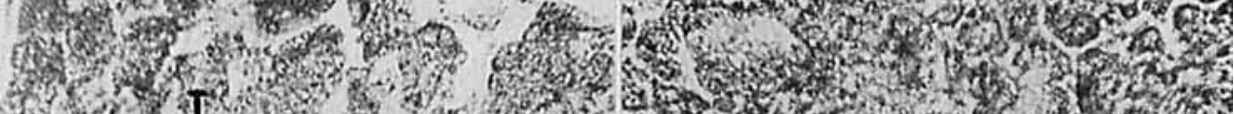

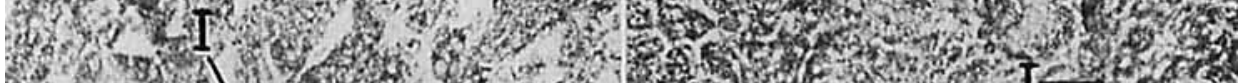

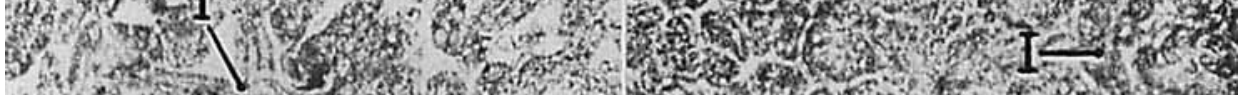

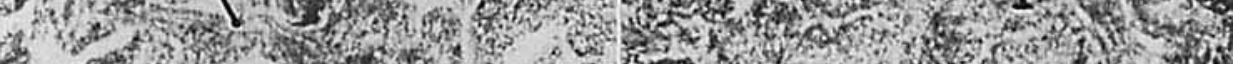

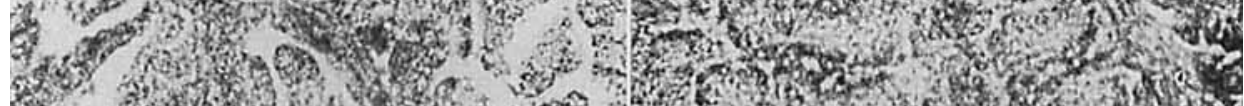

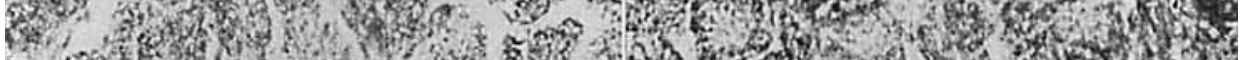
F. 3 \%

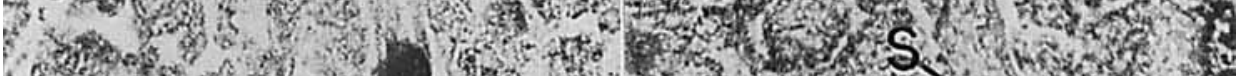

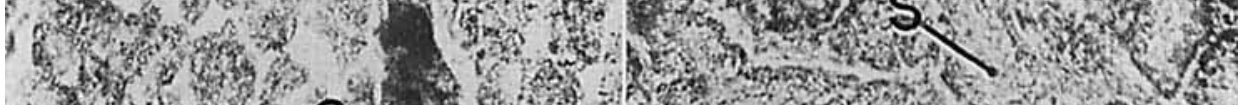

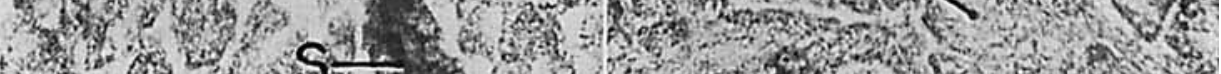

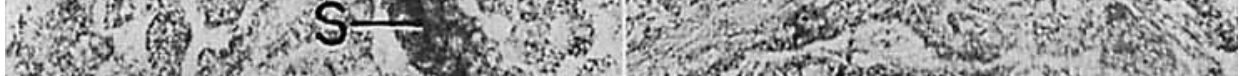

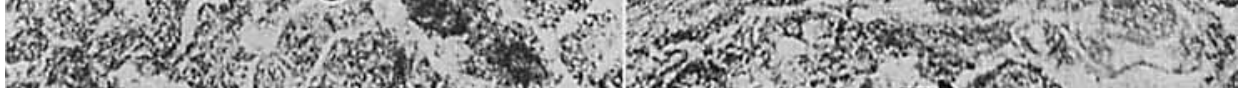

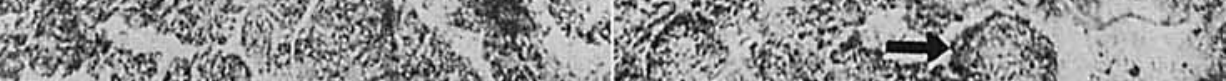
F. 
PLATE 4

EXPLANATION OF FIGURES

Figs. 17, 18 and 19 Unfixed and sectioned in a Cryostat at $10 \mu$; succinic dehydrogenase. $\times 158$.

17 Nouhypophysectomized control. Acinar cells possess suceinic dehydrogenase activity. Droplets within the acinar cells have dissolved neotetrazolium crystals and appear as dark rings. Marked activity is seen in the intercalated, salivary (S) and interlobular (R) ducts.

18 Hypophysectomized 52 days previously. No change is observer in the succinic dehydrogenase activity of the acini, intercalated duet (I), salivary duet (S) and interlobular duet $(\mathbf{R})$.

19 Nonhypophysectomized control. Reduced neotetrazolium is concentrated basally in a large excretory duct.

20 Zymograms prepared according to the method of Hunter and Markert ('57), a-naphthol butyrate as substrate. The dark spots visible on the zymograms are artifacts and due to secondary absorption of the azo-coupled complex. A, Parotid gland 44 days after hypophysectomy. B, Parotid gland from a nonhypophysectomized control. C, Liver from nonhypophysectomized control. 

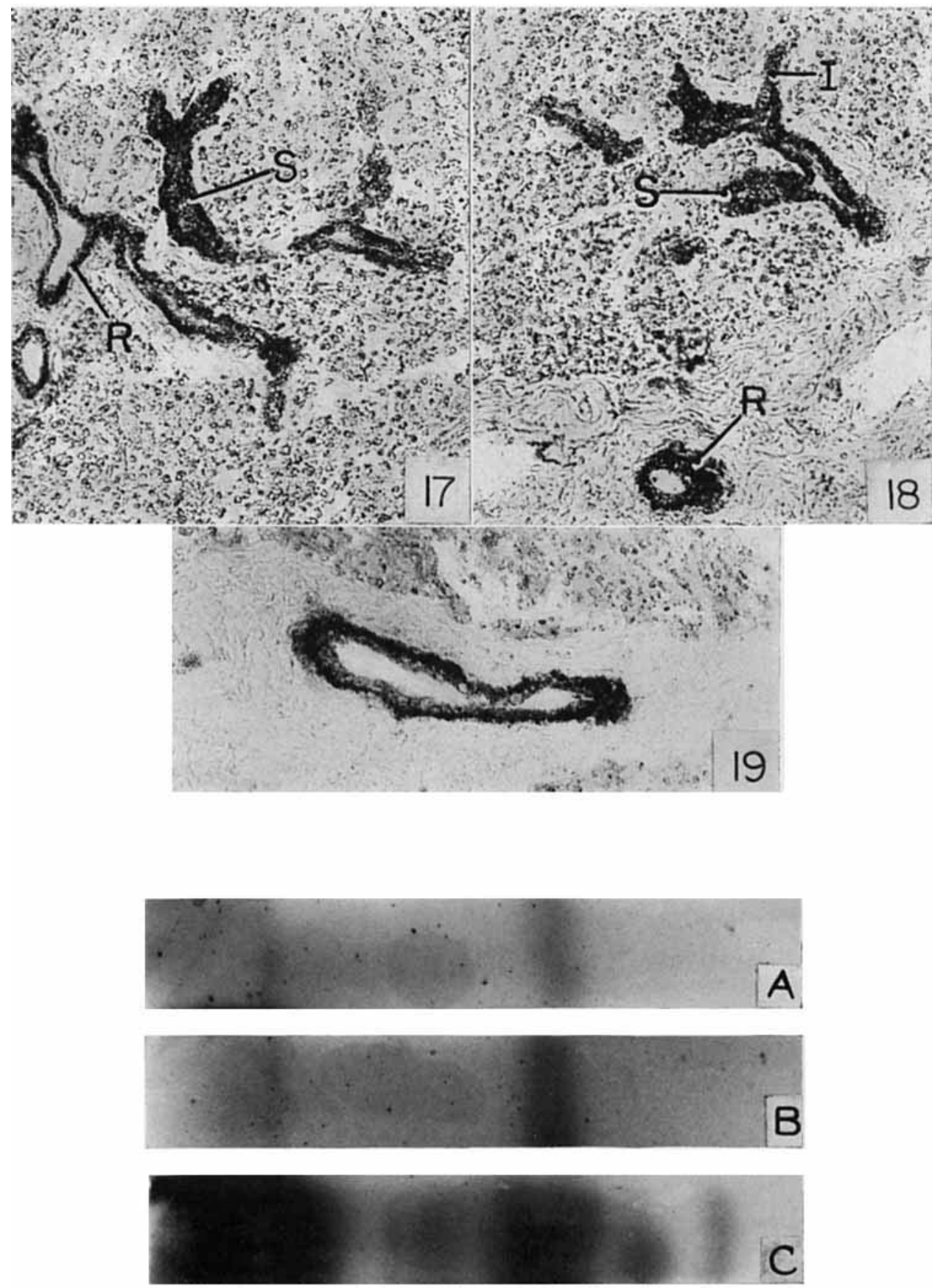